\title{
The Effect of Flipp-Blended Learning Model Using LMS-Google Classroom in Mathematics Learning
}

\author{
Rahmi Ramadhani \\ \{rahmiramadhani3@gmail.com\} \\ Universitas Potensi Utama ${ }^{1}$
}

\begin{abstract}
Blended Learning Model was combined learning model between conventional learning (face-to-face method) and digital learning (online method). This research used flipp-blended learning as conventional problem based learning and LMS-Google classroom as digital learning method.Flipp-Blended Learningwas promoted learning method on 4.0 industry revolution era. Influence noticed of Blended Learning integrated on mathematics subject for first grade college students was this Research objective.Research method used pseudo-experimental research with post-test only control group designtype. Sixty four first grade informatics engineering scholar major was taken as sample for this research.Analyse of examination used Mann-Whitney Test in STATCAL software. Result of this research described that average mathematics test value for scholar whom was taught by combined learning model of Flipp Blended Learning-LMS Google Classroom better than average mathematics test value for scholar whom was taught by conventional learning method. Based on the result, combined learning model of Flipp Blended Learning-LMS Google Classroom was proper to be applied on mathematics learning process in college.
\end{abstract}

Keywords: Flipp-Blended Learning, LMS-Google Classroom, Mathematics Learning

\section{Introduction}

Requirement of 21 st century learning and industry revolution 4.0 is connecting each other, specially for integrating technology on learning process. Technology integration on learning process all this time only using technology as support learning media and not adjusting thoroughly yet. It's opposite to industry revolution 4.0 content where technology not only as learning media but also can be combined to learning models [1]. Paradigm transformation in industry revolution 4.0 is learners as connectors, creators, and constructivist. Based on that, Curiculum can be said as website, students as learning and innovation content producer or connection maker. Available information in industry revolution 4.0 development is not only widely open but also instructor has important role as guide to digital learningcontent and source. Education process is not only focus on learning subject but also using approach in learning method to develop and increase individual education quality; which is explain how to work and live on future efficiently[2].

Blended Learning is one of learning model that explains conventional learning progress step by step, then adds technology on that learning method. Blended Learning also combines traditional learning which is done by telling instruction subject as face to face with learning media based on digital technology. Blended learninggives more space for learning environment efficientlywhich is combining online learning, tradisional learning, learning 
contents and flexibility learning model,then students can be motivated to increase learning process effectivity[3]-[7]. Face to Face Driver, Flip, Rotation, Online Lab, Flex, dan Online Driver are some types of blended learning model[8]. Researcher choosesFlip-Blended Learning model for using in mathematics learning.Teacher's experience more preferred is advantage of Flip-Blended Learningmodel, where learning process more effectively if teacher make learning video than doing talkative learning method. Teacher is expected to adapt with students' missunderstanding in learning material comprehension and create example for matters that can clarify concept to students. Teacher's experience also assists in common problem identification that happenned in learning process and does discussion among students in class, then through Flip-Blended Learning model application, students' comprehension about learning subject and students' interaction is increasing also learning process run more effectively, efficiently and controlled[8], [9].Blended learning application in mathematics also give good influence to increase students' mathematics ability [10].

Flip-Blended Learningmodel that been used on this research is based on LMS-Google Classroom as platform learning system. Platform learning system usage with google classroom on this research because learning system application with google classroom is easy to use for teacher and student. Google classroom is learning management system digital base with complete learning set. User only needs a few configuration to create digital class and develops learning contents as learning material contents or learning evaluation contents [11].

\section{Methodology}

This research usedpseudo-experimental research with post-test only control group design type, flipp-blended learning_LMS google classroom as experimental class and conventional learning class as control class. Research was done during 16 weeks with four hours per weeks for each meeting ( 64 hours for total of learning time) and four hours per weeks for online meeting via LMS-google classroom. LMS-google classroom was applicated alternately with direct learning (face-to-face method). Learning material content, weekly evaluation and final test is prepared on google classroom page. LMS-google classroom also had been used on offline class as learning discussion an enrichment material. Flipp-blended learning model that being used on this research had flexibility application between online learning to offline learning (face-to-face method).

Research result data was obtained from final test as evaluaton for each learning class (experimental class and control class). The given evaluation was five question essay and related to common mathematics subject on informatics technic major, Universitas Potensi Utama. Beside through evaluation, research data was also collected through questionnaire of flip-blended learning with LMS-google classroom application. Data had been analysed with descriptive statistical test (mean and standard deviation) and inferential statistics test (independent sample T-Test). Research result was analysed with STATCAL as statistics tools with 0.05 level with two tails test statistis significant value. Homogenity data evaluation used Kolmogorov-Smirnov test and Levene's Test of Quality for data normality evaluation. 


\section{Result and Discussion}

Students' mathematicsskill score which was taught by used Flipp-Blended Learning Model with LMS-Google Classroom better than conventional learning model. Post-test average score of students' mathematicsskill which was taught by Flipp-Blended Learning Model had good category (79.47), while post-test average score of students' mathematicsskill which was taught by conventional learning model had value for 69,74. Average post-test score distribution of students' skill is described on Table 1.

Table 1.Comparison analysis of the two groups students' mathematics skill scores on post-test

\begin{tabular}{lccc}
\hline Variable & Mean & Standar Deviation & $\mathrm{N}$ \\
\hline Experiment Class & 74,47 & 0,832 & 33 \\
Control Class & 69,74 & 1,090 & 31 \\
\hline
\end{tabular}

Based on Table 1, there was difference about average significant value for two of learning method application. This diversity had greater value than common cases[12]. Distribution of students' post-test score is described on Figure 1.

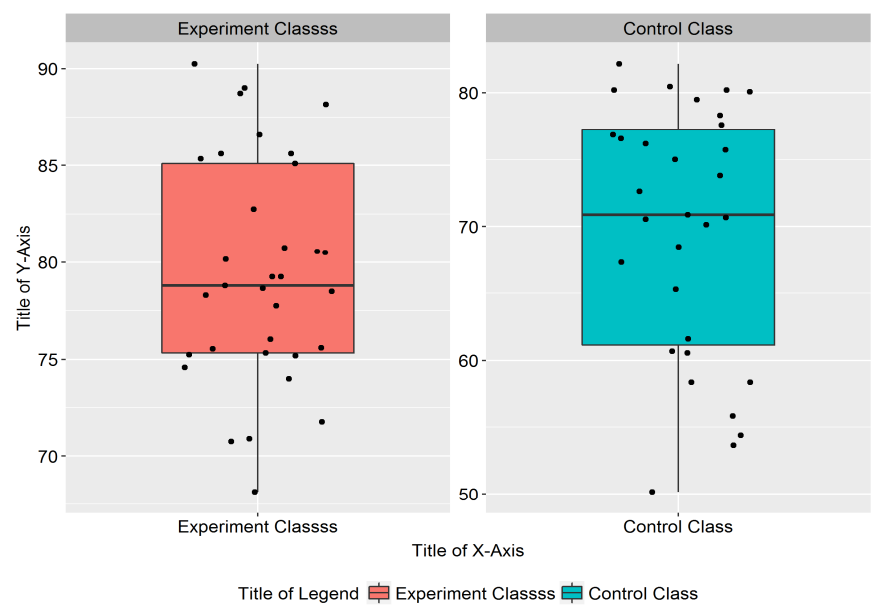

Fig. 1.Boxplot graph of average students' mathematics skill score

Based on boxplot graph above, experimental class post-test value had more disperse distribution data than control class post-test value. It was appropriate to deviation standard value for each learning class ( 0.832 for experimental class and 1.090 for control class). If distribution data hadlower value, then its distribution data was closer to average value, otherwise if distribution had higher value, then ithad wider variation data range [12].

Students' mathematics skill data distribution normality test both in experiment class and control class used Kolmogorov-Smirnov test, while data variance homogeneity test used Levene's test. Normality and homogeneity calculation result test summary is described on Table 2. 
Table 2.Counting result of normality and homogeneity test of students' mathematics skill on post-test

\begin{tabular}{lcc}
\hline Variable & $\begin{array}{c}\text { Test of Normality } \\
\text { (Kolmogorov- } \\
\text { Smirnov) }\end{array}$ & $\begin{array}{c}\text { Test of Homogeneity of } \\
\text { Variances (Levene's } \\
\text { Statistic) }\end{array}$ \\
\hline Experiment Class & 0,1095 & 0,0027 \\
Control Class & 0,1317 & \\
\hline
\end{tabular}

Students' mathematics skill post-test result on experiment class and control class had not same variance (heterogenic or non-homogenic) based on Table 2, because its significant value was smaller than significant standard value $0,05(0,0027<0,05)$. Both their mathematics skill post-test value on experiment class and control class had normal distribution $(0,1095>$ $0,05$ and $0,1317>0,05)$. Based on summary of data normality and homogeneity calculation result test from Table 2, then it can be concluded that students' mathematics skill post-test result data was not relevant to analyse used Independent Sample T-Test, but can be analysed by Mann-Whitney Test[13]. It is displayed on Table 3.

Table 3.Counting result summary Mann-Whitney Test between experiment class and control class

\begin{tabular}{ll}
\hline P-Value without Continuity Correction & 0,0001 \\
\hline P-Value with Continuity Correction & 0,0001 \\
\hline
\end{tabular}

Based on Mann-Whitney Test result (Table 3), it was showed that P-Value with Continuity Correction was smaller than significant standard value $0,05(0,0001<0,05)$. It was concluded that average students' mathematics skill value in experiment class had significantly difference value with average students' mathematics skill value in control class.

Result showed that students' mathematics skill which was taught used flipp-blended learning model with LMS-google classroom had better influence than conventional learning model. Otherwise, usage of flipp-blended learning model with LMS-google classroom connected technology in learning process. Technology provided a way to support content instruction, as well as an opportunity for teachers to be creative in developing class activities to engage students[14]. LMS-google classroom as a digital learning can made students easier to understand about mathematics materials. Students can created active learning environment. Students can worked together and they had interaction each other. Otherwise, mathematics learning process made more interactively and fun. Flipp-blended learning model with LMSgoogle classroom was supported by constructivism and constructionism. It was supported by many researchers like Perkins, Piaget and Vygotsky explained that everyone able to build their knowledge thru environment situation. Students can built new education with investigation and interaction on their surroundings[15].

\section{Conclusion}

Flip-blended learning model application which was combined with LMS-Google Classroom in mathematic learning gave good impact to first grade informatics major college students' learning result. Good influence is not only showed on mathematics learning result, but also can be seen in learning activity. Students was have more passion and enthusiasm for following lesson while flipp-blended learning model that combined with LMS-Google 
Classroom was set. Furthermore, learning situation had been more interesting and interactively due to technology application on learning process. New experience which was obtained made mathematics learning was not scary momment again. Blended learning application on this research was focussed only on flipp type, because of its simplicity and convenience. Also with Google Classroom application as digital learning that is easier for digital class designing suits to learning process requirement. Researcher suggests for developing blended learning model with others learning model or more complex digital learning, then we can get the optimal result for learning method especially for mathematics subject.

\section{References}

[1] I. Ahmad, Proses Pembelajaran Digital dalam Era Revolusi Industri 4,0. Jakarta: Direktur Jenderal Pembelajaran dan Kemahasiswaan, Kementerian Riset, Teknologi dan Pendidikan Tinggi, 2018.

[2] M. Sunggiardi, "Edukasi 4,0 untuk Indonesia," 2018.

[3] F. Harahap and B. Manurung, "The Effect of Blended Learning on Student's Learning Achievement and Science Process Skills in Plant Tissue Culture Course," Int. J. Instr., vol. 12, no. 1, p. 521, 2019.

[4] Y.-W. Lin, C.-L. Tseng, and P.-J. Chiang, "The Effect of Blended Learning in Mathematics Course,” EURASIA J. Math. Sci. Technol. Educ., vol. 13, no. 3, pp. 741-770, Mar. 2017.

[5] F. Alonso, G. López, D. Manrique, and J. M. Viñes, "An instructional model for web-based elearning education with a blended learning process approach," Br. J. Educ. Technol., vol. 36, no. 2, pp. 217-235, 2005.

[6] J. Bersin, The Blended Learning Book: Best Practices, Proven Methodologies, and Lessons Learned. New York: Wiley, 2004.

[7] K. Thorne, Blended Learning: How to Integrate Online and Traditional Learning. London: Kogan Page, 2003.

[8] T. Tsai, J. Lin, and L. Lin, “A Flip Blended Learning Approach for ePUB3 eBook-based Course Design and Implementation,” Eurasia J. Math. Sci. Technol. Educ., vol. 14, no. 1, pp. 123-144, Nov. 2017.

[9] D. R. Garrison and N. Vaughan, Blended learning in higher education: Framework, principles, and guidelines. - PsycNET. San Fransisco, US: Jossey-Bass, 2008.

[10] M. C. Borba, P. Askar, J. Engelbrecht, G. Gadanidis, S. Llinares, and M. S. Aguilar, "Blended learning, e-learning and mobile learning in mathematics education,” $Z D M$, vol. 48, no. 5, pp. 589-610, Aug. 2016.

[11] M. F. Rohman, Learning Management System-SCHOOLOGY. Bojonegoro: Pustaka Intermedia, 2017.

[12] J. Cohen, Statistical Power Analysis for the Behavioral Sciences Second Edition. United States of America: Lawrence Erlbaum Associates, Publishers, 1988.

[13] P. U. Gio and R. C. Caraka, Pedomen Dasar Mengolah Data dengan Program Aplikasi Statistika: STATCAL (Disertai Perbandingan Hasil dengan SPSS \& Minitab). Medan: USU Press, 2018.

[14] K. M. Dicicco, "The effects of Google Classroom on teaching social studies for students with learning disabilities Part of the Special Education and Teaching Commons Recommended Citation," Rowan University, 2016.

[15] R. Ramadhani and S. D. Narpila, "Problem based learning method with geogebra in mathematics learning,” Int. J. Eng. Technol., vol. 7, no. 3.2 Special Issue 2, 2018. 